little to the east of the Dutch-German boundary. It is regarded by the author as a place of exit for the northern migration from Indonesia, and he quotes in full an account of the people by Neuhauss. A vocabulary in the latier's work, "Neu-Guinea" (probably derived from the trader Schulz, described by Neuhauss as a "drunkard" and by Friederici as "a man of no particular intelligence"), is, when corrected by a shorter list of Friederici's, the basis of Mr. Churchill's argument.

Although the words discussed are so few (about 34), the author belittles the existing Melanesian vocabularies, and suggests (without authority) that othersCodrington, Ray, and Friederici-have based their conclusions on these scanty lists.

Mr. Churchill totally ignores the structure of the languages, and does not distinguish between Melanesian and non-Melanesian languages. His lists of cognate words are designed to show their variation from simple stems which the author finds in the Polynesian forms. Thus makan, "eat," is derived from ani; tebu, "sugar-cane," from to. Such derivations are impossibie in Indonesian philology. The former presence of Polynesians throughout Indonesia is regarded as established by the tables. The author supposes them to have been expelled from the archipelago by a more cultured people from the mainland of Asia, who assumed some elements of the Polynesian speech.

Mr. Churchill's comparisons of Melanesian and Polynesian words are open to the same objection as those from Indonesia, for he wili not admit that Polynesian is secondary to Melanesian. He traverses Friederici's suggestion of a Melanesian migration round the eastern end of New Guinea through Vitiaz Strait (cf. NAture, December. 5, I9I3). The whole of the eastern part of the south coast of New Guinea is regarded by the author as belonging to Torres Straits, and the languages there are said to be more Polynesian towards the west. For the western part (i.e. the real Torres Straits region) he says there are no records, and hence he supposes that Polynesian survivals may be found there. This is to support the contention of a Polynesian migration through Torres Straits. But all the languages of New Guinea from the narrows of the Straits to the first Melanesian settlements at Cape Possession are known, and show no Polynesian survivals.

As to the island region of Melanesia, Mr. Churchill quotes from Dr. Rivers's "Melanesian Society" the chapter on kava and betel, but will not allow a possible origin of the kava culture in Melanesia.

Mr. Churchill's book is interesting, especially in its descriptive parts, and his views as to the directions of the migrations are clearly set forth in a series of charts. He does not disguise the difficulties of his thesis, but his desire to establish the pre-eminence of Polynesian among the languages of the Pacific has caused him to overlook many details which seriously militate against the soundness of his argument.

SIDNEY H. RAY.

\section{CANADIAN EXPLORATION.}

$S O M E$ information on the work of the Canadian Arctic Expedition additional to that alreadv pub. lished appears in the Geographical Review for October (vol. iv., No. 4). The whole of the coast-line from Cape Bathurst to the eastern end of Coronation Gulf, except Cape Parry peninsula, was surveyed on a scale of ten miles to an inch. The surveys were extended to include Croker River and Rae River. Other surveys included much of the Mackenzie delta. The most important geological research of the southern party, with whose work this paper by $\mathrm{Mr}$. R. M. Anderson deals, was the investigation of the copper-bearing rocks in the region of Bathurst Inlet. They occur on Banks Peninsula and most of the islands to the north of it. Though the ore so far discovered is of low grade, Dr. O'Neill, the geologist of the expedition, estimated the amount of ore at more than two billion tons, and believes that it can be profitably utilised. Water transport round Alaska would be long and uncertain, but a short railway to Great Bear Lake would probably solve the difficulty of export. The article is illustrated with two sketch maps and a number of valuable photographs.

The Geological Survey of Canada has published, as Memoir 84, a volume by Mr. C. Camsell on an exploration of the Tazin and Taltson Rivers in the NorthWest Territories. The exploration of this region between Lake Athabaska and the Great Slave Lake was undertaken by the author in I9I4 by a canoe traverse from south to north. A compass survey was made and checked almost daily by sextant observations. The report is mainly geological and is accompanied by a geologioal map on a scale of 8 in. to a mile, and by a number of good illustrations. Neither the Tazin nor the Taltson proves to be navigable, except for short stretches, on account of falls and strong rapids. The country abounds in lakes. The lack of soil, apart from climatic difficulties, makes agriculture impossible. The inhabitants are a few nomadic Indians of the Chipewyan and Dogrib stocks.

\section{EFFECTS OF STORAGE UPON COAL.}

A FURTHER contribution to the study of the effect A of storage on the properties of bituminous coals has been issued from the Engineering Experimental Station, University of Illinois (Bull. 97). Prof. S. W. Parr, who has been associated with Wheeler, Barker, and Kressman in a series of experiments started in 1910, summarises the conclusions arrived at, and records further investigations; more particularly of interest are those on the action of pyrites and the tests of weathered coals under boilers. The general conclusions that freshly mined coal has a large absorptive capacity for oxygen, the degree being dependent on the character of the coal; that the rate of absorption depends upon fineness of division and temperature; that such oxidation leads to slight increase of temperature, and if not radiated more rapidly than generated the action accelerates to a dangerous point $\left(180^{\circ} \mathrm{F}\right.$. is named), have for some time been recognised as the main causes of spontaneous ignition. Parr concludes that the well-recognised loss of thermal value on storage is more apparent than real, being largely due to increase of weight due to oxygen absorption.

Much difference of opinion exists as to the part played by pyrites $\left(\mathrm{FeS}_{2}\right)$ in promoting heating. Experiments are recorded showing the increase of soluble sulphates in coal of various grades of fineness on storage. Fine grades 1 show marked increase, but only in one case of coal passing a ten-mesh sieve was any increase noted. It is concluded that to lead to sulphur oxidation two conditions are necessary: fineness of division and presence of moisture. It had been previously shown that the oxidation of 0.5 per cent. of sulphur produced sufficient heat to raise the coal, not allowing for radiation losses, about $125^{\circ} \mathrm{F}$. Finely divided pyrites, therefore, may well materially assist in promoting heating by itself, raising the temperature to such a point that oxygen absorption is greatly accelerated. It is shown that whilst the heating value of stored coal is materially reduced, such weathered coal gives over-all boiler efficiencies as high as fresh coal, provided a higher draught is used and the fire kept thin and clear of the water-back of the grate, otherwise clinker trouble is experienced. 